\title{
Development and morphology of the fruit and seed of the hemiparasite genus Jodina (Cervantesiaceae)
}

\author{
María Luján Luna ${ }^{1 *}$, Gabriela E. Giudice ${ }^{1}$, Mariana A. Grossi ${ }^{2} \&$ Diego G. Gutiérrez ${ }^{3}$ \\ ${ }^{1}$ Facultad de Ciencias Naturales y Museo,Universidad Nacional de La Plata, Boulevard 120 y 61, B1900FWA, \\ La Plata, Argentina; lujanluna@fcnym.unlp.edu.ar \\ ${ }^{2}$ División Plantas Vasculares, Museo de La Plata, FCNyM, UNLP, Paseo del Bosque s.n., B1900FWA, \\ La Plata, Argentina \\ ${ }^{3}$ División Plantas Vasculares, Museo Argentino de Ciencias Naturales (MACN, CONICET), \\ Avda. Angel Gallardo 470, C1405DJR, Buenos Aires, Argentina
}

\begin{abstract}
Luna, M.L., Giudice, G.E., Grossi, M.A. \& Gutiérrez, D.G. 2017. Development and morphology of the fruit and seed of the hemiparasite genus Jodina (Cervantesiaceae). Anales Jard. Bot. Madrid 74(1): e051.

The monotypic genus Jodina is endemic to central and southeastern South America, common in forests and scrubland environments. The fruit type in Jodina is controversial since it has been described at different stages of development. The main objective of this work was to analyze the morphology of the fruit of $J$. rhombifolia during its maturation to attain a consensus about its type. Also characteristics of seed development and anatomy were analyzed in detail. Material was processed according to conventional techniques for LM and SEM studies. The fruit of J. rhombifolia is a pseudodrupe since the ovary is half-inferior; the fleshy layer of the pericarp is constituted by an increase of the nectary disk whereas the stony layer is represented by the mesocarp. Participation of the nectary disk as part of the fruit wall has not been mentioned previously. The seed is "naked" - the integument disintegrates during development - and the resulting structure is a pyrene. The interpretations made by other authors on the fruit of Jodina are also discussed.
\end{abstract}

Keywords: Anatomy, Jodina rhombifolia, nectary disk, pseudodrupe, pyrene.

\section{Resumen}

Luna, M.L., Giudice, G.E., Grossi, M.A. \& Gutiérrez, D.G. 2017. Desarrollo y morfología del fruto y la semilla del género hemiparásito Jodina (Cervantesiaceae). Anales Jard. Bot. Madrid 74(1): e051.

El género monotípico Jodina es endémico del centro y sureste de América central, común en bosques y ambientes de matorral. El tipo de fruto en Jodina es controvertido, ya que se ha descrito en diferentes etapas de su desarrollo. El principal objetivo de este trabajo fue analizar la morfología del fruto de J. rhombifolia durante su maduración para alcanzar un consenso sobre su tipo. Asimismo, se analizaron en detalle diferentes características del desarrollo y la anatomía de la semilla. El material se estudió de acuerdo con las técnicas convencionales utilizadas en estudios con MO y MEB. El fruto de J. rhombifolia es una pseudodrupa, dado que el ovario es semiínfero; la capa carnosa del pericarpio está constituida por un engrosamiento del disco y la capa dura está representada por el mesocarpio. La participación del disco como parte de la pared del fruto no se ha mencionado anteriormente. La semilla es "desnuda" — el tegumento se desintegra durante el desarrollo- y la estructura resultante es un pireno. Se discuten asimismo las interpretaciones realizadas por otros autores acerca del fruto de Jodina.

Palabras clave: Anatomía, disco glandular, Jodina rhombifolia, pireno, pseudodrupa.

ORCID ID: M.L. Luna (http://orcid.org/0000-0001-7025-782X); G.E. Giudice (http://orcid.org/0000-0003-1352-4009); M.A. Grossi (http://orcid. org/0000-0002-9837-9156); D.G. Gutiérrez (http://orcid.org/0000-0001-9292-235X).

Received: 30-III-2016; accepted: 8-IX-2016; published online: 3-V-2017; Associate Editor: Pedro Luis Ortiz.

Copyright: ( 2017 CSIC. This is an open-access article distributed under the terms of the Creative Commons Attribution-Non Commercial (by-nc) Spain 3.0 License.

\section{INTRODUCTION}

According to the more recent phylogeny inferred from DNA sequences, Cervantesiaceae Nickrent \& Der includes 8 genera that formerly belonged to Santalaceae R. Br. s.l. (Der \& Nickrent, 2008; Nickrent \& al., 2010). However, the classical concept of Santalales R. Br. ex Bercht. \& J. Presl and its families based on morphology (v.gr., Cronquist, 1981; Takhtajan, 1997) are followed by other researchers (v.gr., Kuijt \& Hansen, 2015). Cervantesiaceae is formed by hemiparasitic trees or shrubs with thorns, bisexual or unisexual flowers, solitary or grouped in inflorescences, 4-5-merous campanulate or urceolate corollas, hairs on the petals that are opposite to and in equal number with the stamens, and a nectary disk often with lobes alternating between the petals (Nickrent \& al., 2010).

Currently this family is formed by genera Acanthosyris (Eichler) Griseb., Cervantesia Ruiz \& Pav., Jodina Hook. \& Arn. ex Meisn., Okoubaka Pellegrin \& Normand, Pilgerina Z.S. Rogers \& al., Pyrularia Michx., Scleropyrum Arn., and Staufferia Z.S. Rogers \& al., all them mainly from template and Andean South America, tropical Africa and Madagascar, template and tropical Asia reaching Malesia, and one species from the southeastern North America. It was claimed that the intergeneric relationship within this family was totally resolved, and it was composed of two monophyletic groups. One of them, the Cervantesia group, includes all South American genera, Acanthosyris, 
Cervantesia, and Jodina. These genera show shared features such as an unilocular ovary with a twisted placental column, although the position of the ovary varies, being half-inferior - Acanthosyris-, superior - Cervantesia-, or inferior -Jodina - (Nickrent \& al., 2010).

Among them, Jodina is the southernmost genus, endemic to central and southeastern South America, where it grows from Bolivia, extreme southern Brazil, Uruguay, and Argentina, reaching there its southernmost distribution range, approximately in the north of Colorado River in Buenos Aires and La Pampa Provinces (Luna \& De la Sota, 2003; Dettke \& Caires, 2016). This is a monotypic genus with the species J. rhombifolia (Hook. \& Arn.) Reiss., called "sombra de toro" or "peje". Jodina rhombifolia is a tree up to $8 \mathrm{~m}$ tall, with rhombic and glabrous leaves, and 3 spines on the free ends (Luna \& de la Sota, 2003; Kuijt \& Hansen, 2015). One of its more interesting characteristics is to be a hemiparasite plant, having been encountered haustorial connections with roots of Celtis tala Gillies ex Planch. and Scutia buxifolia Reissek (Luna \& Giudice, 2005). In relation to the reproductive features, Jodina has bisexual flowers, a nectary disk that alternates with the petals, and a fleshy fruit with a single seed (Kuijt \& Hansen, 2015).

The fruits of Cervantesiaceae and Santalaceae s.l. were mentioned in general terms as drupaceous with a stony pit (Der \& Nickrent, 2008; Rogers \& al., 2008) or as true drupes (Nickrent \& al., 2010; Kuijt \& Hansen, 2015). With regard to Jodina, different types of fruit have been described. Following Dawson (1944) and Rodríguez Mattos (1967), the fruit of $J$. rhombifolia is a drupaceous capsule because the "tepals" are deciduous at maturity. Then, Bhatnagar \& Sabharwal (1969) defined this fruit as a pseudodrupe, since the stony layer of the fruit wall is the mesocarp. According to Kuijt \& Hansen (2015), Jodina has a drupe-like fruit with a stony endocarp, and a fleshy rugose exocarp that detaches into 5 parts at maturity. The drupe has been broadly defined as an indehiscent, and singled seeded fruit with a fleshy-stony pericarp, being the stony portion constituted by the endocarp (Roth, 1977, 1987). Transitional types may be found, giving rise to concepts such as pseudodrupe or drupaceous fruit for those with fleshy exocarp and undifferentiated endocarp, or with stony mesocarp (Spujt, 1994). On the development and anatomy of J. rhombifolia seed, the only published works were those of Bhatnagar \& Sabharwal (1966, 1969), which emphasized on endospermogenesis and the early stages of embryo development.

Because the type of fruit is an important feature used in Systematics, and the available information on the development and structure of the fruit of Jodina is scarce and controversial, the main objective of this work was to study its fruit structure and seed morphology at different developmental stages.

\section{MATERIAL Y METHODS}

Flowers, fruits, and seeds of J. rhombifolia were collected at Partido de Magdalena - $35^{\circ} 11^{\prime} \mathrm{S}, 57^{\circ} 17^{\prime} \mathrm{W}$, northeastern Buenos Aires Province, Argentina - from May to December during the years 2011-2013. Thus, different stages of fruit and seed development were covered, from immature fruits with greenish persistent petals enclosing the pericarp and developing seed - about 3-4 months after anthesisto more mature stages of fruit and seed formation, with the reddish persistent petals or when they were detached exposing the white fleshy covering - 5-6 months after anthesis-. Ripe seeds, considered at this stage once the fleshy covering has disorganized - near 7 months after anthesis-, were also collected. The number of trees sampled during the three years was around 60 . The voucher specimens were deposited at herbarium LP -ARGENTINA. Buenos Aires, Pdo Magdalena, Estancia San Isidro, 23-V-2011, M.L. Luna 114 \& al.; ibídem, 7-IX-2011, M.L. Luna 135 \& al.; ibídem, 16-VII-2012, M.L. Luna 142 \& al.; ibídem, 21-X-2012, M.L. Luna 150 \& al.; ibídem, 15-XII-2012, M.L. Luna 154 \& al.; ibídem, 5-VI-2013, M.L. Luna 161 \& al.; ibídem, 14-VIII-2013, M.L. Luna 167 \& al.

For light microscopy analyses - LM-, flowers, fruits, and seeds at different stages of development were fixed in formaldehyde-acetic acid-alcohol, dehydrated through an ethanol series and embedded in Paraplast. Sections - 8-10 $\mu \mathrm{m}$ thick - were double stained with safranin-fast green (Johansen, 1940).

Other staining procedures were used, such as iodinepotassium iodide for amyloids (Kooiman, 1960), periodic acid-Schiff - PAS - for carbohydrates (O'Brien \& Mc Cully, 1981), and the following fluorochromes: Nile blue for neutral lipids and 8-anilino-1- naphthalene-sulphonic acid for proteins - for both: BV filter, main length wave $463 \mu \mathrm{m}-$ (Fulcher, 1982). Observations were made in a Nikon Microphot- FX epifluorescence microscope.

For scanning electron microscopy - SEM-, flowers were fixed in formalin: propionic acid: ethyl alcohol - 0.5:0.5:9 —, dehydrated in ethanol-acetone series and critical point dried using $\mathrm{CO}_{2}$ (Sancho \& Otegui, 2000). The seeds were analyzed under SEM without pre-treatment. In both cases, materials were mounted on double-sided tape on aluminum stubs, sputter coating with gold-palladium and examined with a Jeol JSM-T100 microscope.

Crude protein in endosperm was determined preliminary by the Macro-Kjeldahl method whereas fats were calculated by continuous extraction with a Soxhlet extractor, using benzene as solvent (Bullock \& Moore, 1992).

\section{RESULTS}

The previous descriptions reported in the literature for the fruit type of J. rhombifolia are summarized in Table 1.

\section{Morphology of the flower}

The flowers were bisexual and monochlamydeous, tetramerous or pentamerous $-1: 1-$ (Fig. 1a). Following Nickrent \& al. (2010) and Kuijt \& Hansen (2015), we assumed the single floral whorl as the corolla. Stamens were opposite and epipetalous; the nectary disc showed lobes that alternated with the petals (Fig. 1a, b). The number of lobes of the nectary disk was 4 or 5 , in coincidence with the number of petals, and they were not vascularized. The ovary was half-inferior, tricarpellar, and unilocular. The twisted vascularized placenta bore 2 ovules which were anatropous and unitegmic (Fig. 1b, d). Parts of the corolla and nectary disk underwent changes in connection with the fruit development (Table 2). 
Table 1. Jodina rhombifolia fruit type, origin of fruit layers, and comments according to different authors.

\begin{tabular}{|c|c|c|c|c|}
\hline & Fruit type & Origin of the fleshy layer & Origin of the stony layer & Comments \\
\hline Dawson (1944) & Drupaceous capsule & Probably epicarp + endocarp & Endocarp & $\begin{array}{l}\text { The "tepals" are modified when the } \\
\text { fruit ripens, and they are the } 5 \text { (or } 4 \text { ) } \\
\text { deciduous segments at maturity. }\end{array}$ \\
\hline Nickrent \& al. (2010) & Drupe & "Inner exocarp" & Mesocarp & $\begin{array}{l}\text { The five perianth valves extend } \\
\text { basipetally upon fruiting. Then, the } \\
\text { "outer exocarp" dehisces. }\end{array}$ \\
\hline Kuijt \& Hansen (2015) & Drupe-like & Exocarp & Endocarp & $\begin{array}{l}\text { The exocarp divides into } 5 \text { longitudinal } \\
\text { parts separating at maturity. }\end{array}$ \\
\hline
\end{tabular}
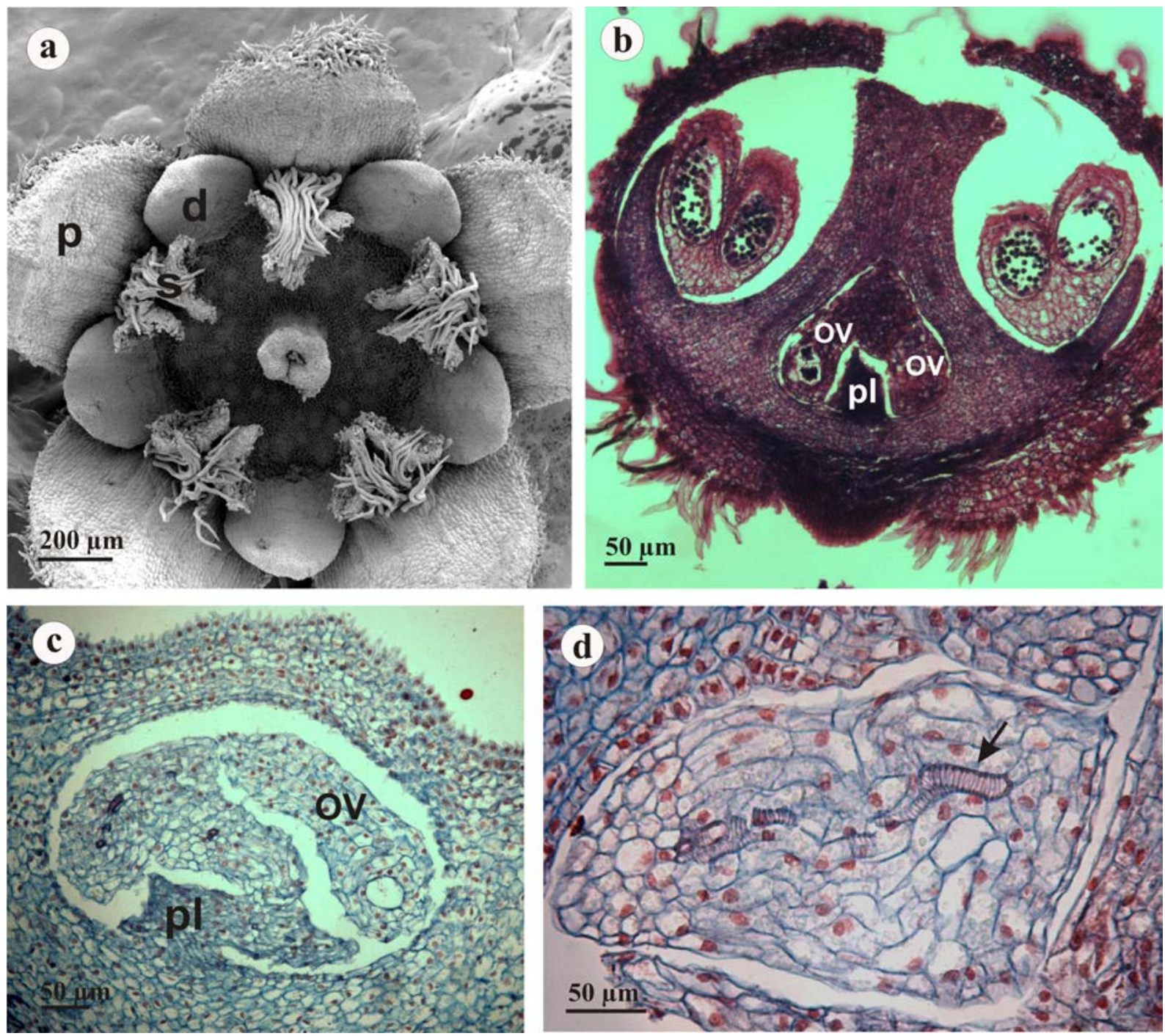

Fig. 1. Flower structure: a, scanning electron micrograph of a flower with 5 petals, the 5 lobes of the nectary disk alternating with them, the stamens epipetalous, bearing hairs behind them; $\mathbf{b}$, longitudinal section showing half-inferior position of the ovary, the placenta bearing 2 ovules; $\mathbf{c}$, detail of twisted and vascularized placenta; d, magnification of tracheids (arrow) in placenta. [Abbreviations: p, petal; d, nectary disk; st, stamen; s, stigma; ov, ovule; pl, placenta.] 
Table 2. Changes recorded in the structures and tissues involved in Jodina rhombifolia fruit and seed development.

\begin{tabular}{|c|c|c|c|c|}
\hline & 40-50 DAA & 70 DAA & 90 DAA & 150-180 DAA \\
\hline Petals & $\begin{array}{l}\text { Greenish, almost completely } \\
\text { enclosing the developing } \\
\text { fruit. }\end{array}$ & $\begin{array}{l}\text { Greenish. They have grown } \\
\text { by successive mitosis and } \\
\text { enclosed completely the fruit. }\end{array}$ & $\begin{array}{l}\text { Greenish, somewhat } \\
\text { wrinkled. They continue } \\
\text { to increase in size with the } \\
\text { growth of the fruit. }\end{array}$ & $\begin{array}{l}\text { Reddish and wrinkled. Then } \\
\text { detached. }\end{array}$ \\
\hline Epicarp & $\begin{array}{l}\text { Made up of the epidermis } \\
\text { and 3-4 layers of parenchyma } \\
\text { cells. }\end{array}$ & $\begin{array}{l}\text { As in the previous stage. Cell } \\
\text { divisions are registered. }\end{array}$ & Cell divisions are stopped. & Disintegrated. \\
\hline Endocarp & $\begin{array}{l}\text { Vascularized. Consisting } \\
\text { of } 22 \text { to } 30 \text { layers of } \\
\text { parenchyma cells containing } \\
\text { starch grains and rhombic } \\
\text { crystals of calcium oxalate. }\end{array}$ & $\begin{array}{l}\text { Starts to be consumed by the } \\
\text { haustorial endosperm. Cell } \\
\text { divisions are observed. }\end{array}$ & $\begin{array}{l}\text { Continues to be consumed by } \\
\text { the haustorial endosperm. }\end{array}$ & $\begin{array}{l}\text { Reduced to a few } \\
\text { papyraceous layers. }\end{array}$ \\
\hline $\begin{array}{l}\text { Cellular portion of } \\
\text { endosperm }\end{array}$ & Cell divisions are registered. & $\begin{array}{l}\text { Consisting of a greater } \\
\text { number of cells than in the } \\
\text { previous stage. Cell divisions } \\
\text { are observed. }\end{array}$ & Cell divisions continue. & $\begin{array}{l}\text { With thin cell walls. Cells } \\
\text { containing lipids, protein } \\
\text { bodies and starch grains. }\end{array}$ \\
\hline $\begin{array}{l}\text { Haustorial portion of } \\
\text { endosperm }\end{array}$ & $\begin{array}{l}\text { Present, with starch grains. } \\
\text { Appears consuming the } \\
\text { placenta, which is almost } \\
\text { completely disintegrated. }\end{array}$ & $\begin{array}{l}\text { It has consumed completely } \\
\text { the placenta and the ovule } \\
\text { integument, then going } \\
\text { towards the endocarp. }\end{array}$ & $\begin{array}{l}\text { Consuming the endocarp, } \\
\text { which appears almost } \\
\text { completely disintegrated. }\end{array}$ & Absent. \\
\hline Embryo & Not observed. & $\begin{array}{l}\text { Globular stage, with starch } \\
\text { grains. }\end{array}$ & $\begin{array}{l}\text { Heart-shape and torpedo- } \\
\text { shape stages. }\end{array}$ & $\begin{array}{l}\text { Embryo incurved, with } \\
\text { starch grains in all tissues. }\end{array}$ \\
\hline
\end{tabular}

\section{Morphology and development of the fruit}

During the development of the fruit, petals were persistent and increased in size, becoming reddish as the fruit was ripening. Some 50 days after anthesis - DAA - (Table 2), the developing pericarp with its typical 3 layers - epicarp, mesocarp, and endocarp - was observed beneath the petals (Fig. 2a). At this stage, all of the layers underwent cell divisions. Early stages of the endosperm development were detected in one of the ovules, showing the haustorial and cellular portions. At the apical zone of the fruit, the epicarp included the epidermis and 3-4 layers of parenchyma cells (Fig. 2b). Following inward, the mesocarp was constituted by 4-5 layers of parenchyma cells compactly arranged. More inwards the endocarp appeared, which was vascularized and consisted of 20-30 layers of parenchyma cells with abundant starch grains and calcium oxalate crystals. Towards the middle zone of the fruit, the epicarp merged with the nectary disk, which had grown by successive mitosis (Fig. 2c).

Near 70 DAA (Table 2), the 3 layers of the pericarp still underwent cell divisions. The haustorial portion of the endosperm directed towards the endocarp and started to consume their reserves (Fig. 2d, e). About 90 DAA (Table 2) cell divisions stopped in both epicarp and mesocarp, while they continued to occur in the endocarp. At this point, the innermost layers of the endocarp were still digested by the haustorial portion of the endosperm (Fig. 2f). Sclerification of the mesocarp began to occur when endosperm was mostly cellular, and it took place from the apical to the basal zone of the fruit (Fig. 2g, h). This process was accompanied by deposition of calcium oxalate crystals (Fig. 2i).

The fruit reached the mature stage about 150 DAA. As the fruit was ripening, the persistent petals became reddish and wrinkled (Fig. 3a). Beneath them the nectary disk underwent changes forming a whitish, fleshy, and sweet taste covering which almost completely surrounded the pericarp except at the apical zone (Fig. 3b). This fleshy layer was composed up of 10-15 layers of parenchyma cells.

Approximately 180 DAA (Table 2), the petals were released and the epicarp disintegrated (Fig. 3c). The fleshy covering surrounded the stony and smooth mesocarp that remained exposed at the apical zone of the fruit (Fig. 3d). Depending on the number of lobes of the nectary disk, the fleshy layer of the fruit consisted of 4 or 5 segments. The mature fruit was near $7 \times 9 \mathrm{~mm}$ in size.

\section{Morphology and development of the seed}

Approximately 40 DAA, endosperm development was recorded in only one ovule - the other ovule disorganized-. It comprised the haustorial portion, that remained unicellular during development, and the cellular portion which underwent mitotic divisions (Fig. 4a).

At near 50 DAA (Table 2) the haustorial portion branched and primarily consumed the placenta and then the integument of the ovule, meanwhile the cellular portion continued under cell divisions (Fig. 4b). Because the 

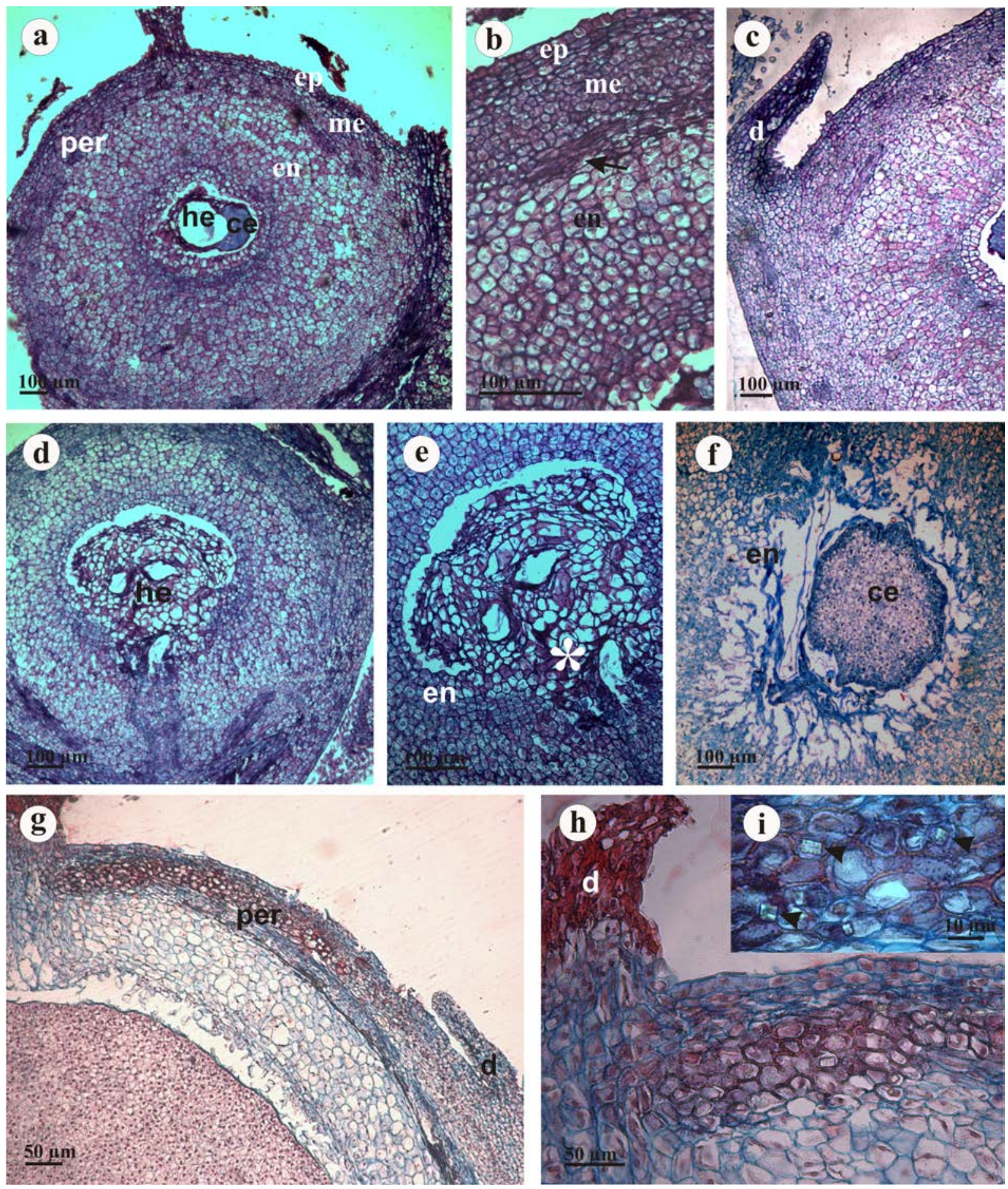

Fig. 2. Different stages of fruit wall development: a, earlier stage of fruit wall development where epicarp, mesocarp and endocarp are observed, the cellular and haustorial portions of the endosperm are also detected; $\mathbf{b}$, detail of the different layers of the fruit wall, the endocarp is vascularized (arrow); c, portion of the fruit wall showing that the nectary disk is merged with the pericarp and accompanies its development; d, more advanced stage in which the haustorial portion of the endosperm begins to consume the endocarp; $\mathbf{e}$, detail of haustorial endosperm (asterisk) moving towards the endocarp; f, somewhat later increased disorganization of the endocarp is observed; $\mathbf{g}$, step of fruit wall development in which sclerification of the mesocarp is recorded, at this moment the endosperm is almost completely cellular; $\mathbf{h}$, a more detailed view of stony mesocarp; $\mathbf{i}$, magnification of mesocarp showing deposit of crystals (arrowheads). [Abbreviations: per, pericarp; ep, epicarp; me, mesocarp; en, endocarp; d, nectary disk lobe; he, haustorial endosperm; ce, cellular endosperm.]

integument was completely disintegrated in this process, the seed was considered naked. About 70 DAA (Table 2), both the placenta and the integument of the ovule were completely consumed by the haustorial portion of the endosperm. The cellular portion of the endosperm continued under mitotic divisions increasing its volume (Fig. 4c). At this step, it was recorded the globular stage of pro-embryo with starch contents (Fig. 4d). Near 130 DAA (Table 2), the endosperm was completely cellular (Fig. 4e). Its thinwalled cells, PAS positive, accumulated starch grains, 

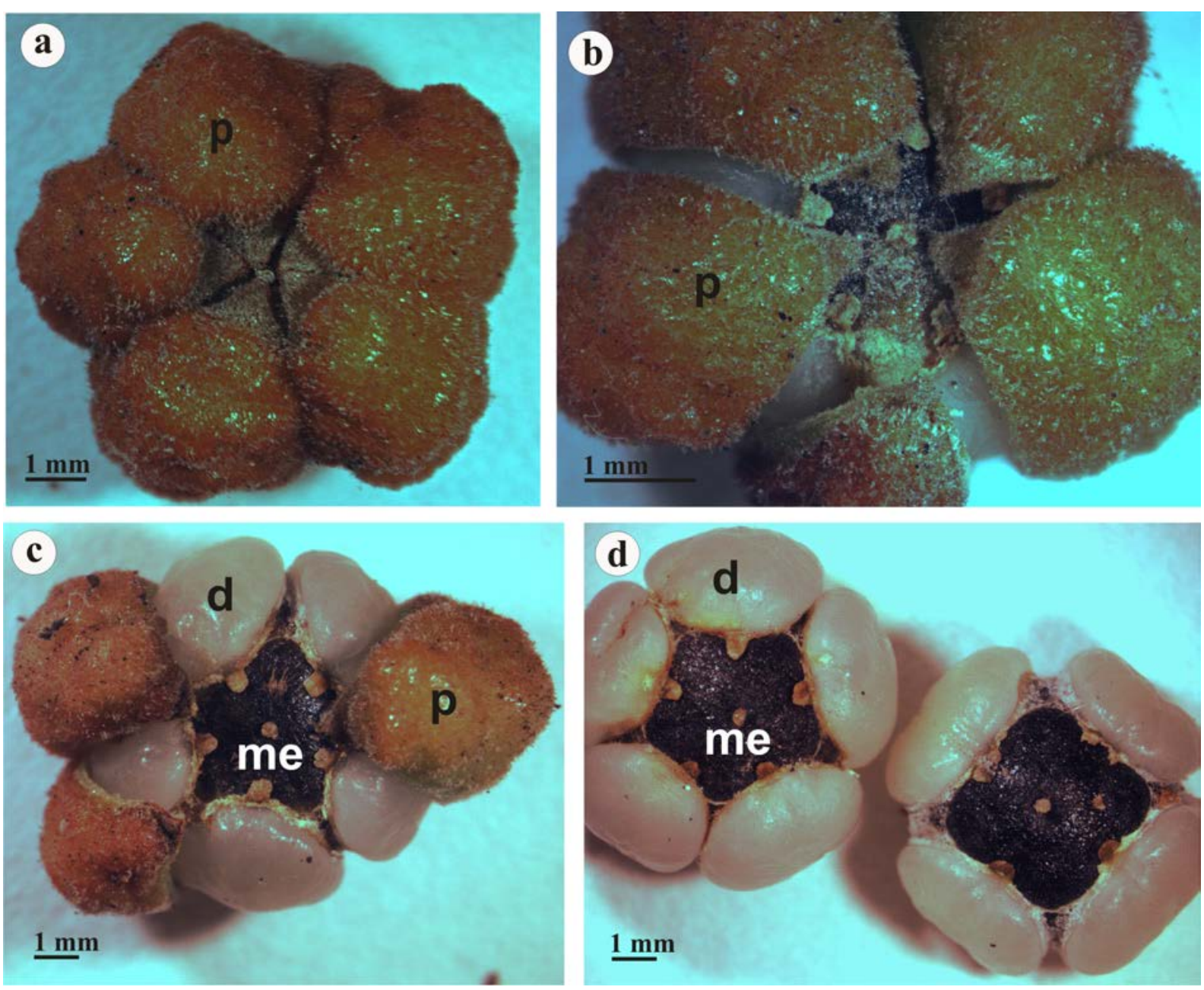

Fig. 3. Macroscopic views of fruits at various steps of maturation: a, fruit with persistent reddish petals; $\mathbf{b}$, after a while the petals start to wrinkle and separate, exposing the modified nectary disk; $\mathbf{c}$, in a more advanced stage of maturity the petals begin to come off, leaving the disc completely exposed; $\mathbf{d}$, in a late stage of ripening the fruit wall is constituted by the disc plus the stony mesocarp, the image reveals that the nectary disk may have 4-5 lobes. [Abbreviations: p, petal; nd, nectary disk; d, nectary disk; me, mesocarp.]

lipids, and protein bodies (Fig. 4e, f). Along with the development of the endosperm (Fig. 5a), the heart-shaped and torpedo-shaped pro-embryo stages were observed. The embryo was incurved and the cotyledons showed abundant chloroplasts and starch grains (Fig. 5c, d). Xylem elements - tracheids - were observed frequently in the endosperm, next to the mature embryo (Fig. 5e, f). Near 180 DAA (Table 2), the "seed coat" was constituted by the remains of endocarp, which had become papyraceous, together with the stony mesocarp (Fig. 5g).

The pyrene -i.e., seed plus mesocarp- was subspheroidal, with somewhat flattened poles, and ca. $5 \times 7 \mathrm{~mm}$ (Fig. 5h). Raw protein content in the endosperm was ca. $20 \%$, while the lipids reached ca. $68 \%$.

\section{DISCUSSION}

The fruit of Jodina is a pseudodrupe, since the fruit wall is constituted by the persistent reddish petals, along with the modified nectary disk - "white fleshy layer" - plus the sclerified mesocarp. Actually, this "white fleshy layer" of the fruit, which corresponds to the modified nectary disk, has not been mentioned previously for this genus.
The development of the nectary disk after fertilization and its persistence in the mature fruit has been cited only for Quinchamalium Molina (Johri \& Agarwal, 1965), a genus of Schoepfiaceae Blume (sensu Nickrent \& al., 2010), a basal family of the Santalales. However the authors have not considered the modified nectary disk when described the fruit wall of Quinchamalium chilense Lam. Following Spujt (1994), pseudodrupes also include fruits with "accessory structures" - like the nectary disk—, as part of the fruit wall.

Description of the fruit at different stages of development leads to its classification in different types. In this sense, the fruit of Jodina has been described in a less mature stage when petals have not yet fallen off, or in a more mature stage after their detachment (Table 1). Bhatnagar \& Sabharwal (1966) also classified the fruit of Jodina as a pseudodrupe, but in this case considering the persistent perianth as the fleshy layer. Furthermore, Heide-Jørgensen (2008) described as 5 carpels the modified and persistent reddish petals of J. rhombifolia - as already mentioned, the gynoecium is tricarpellary.

Taking into account the Cervantesiaceae, Der \& Nickrent (2008) and Nickrent \& al. (2010) mentioned that 

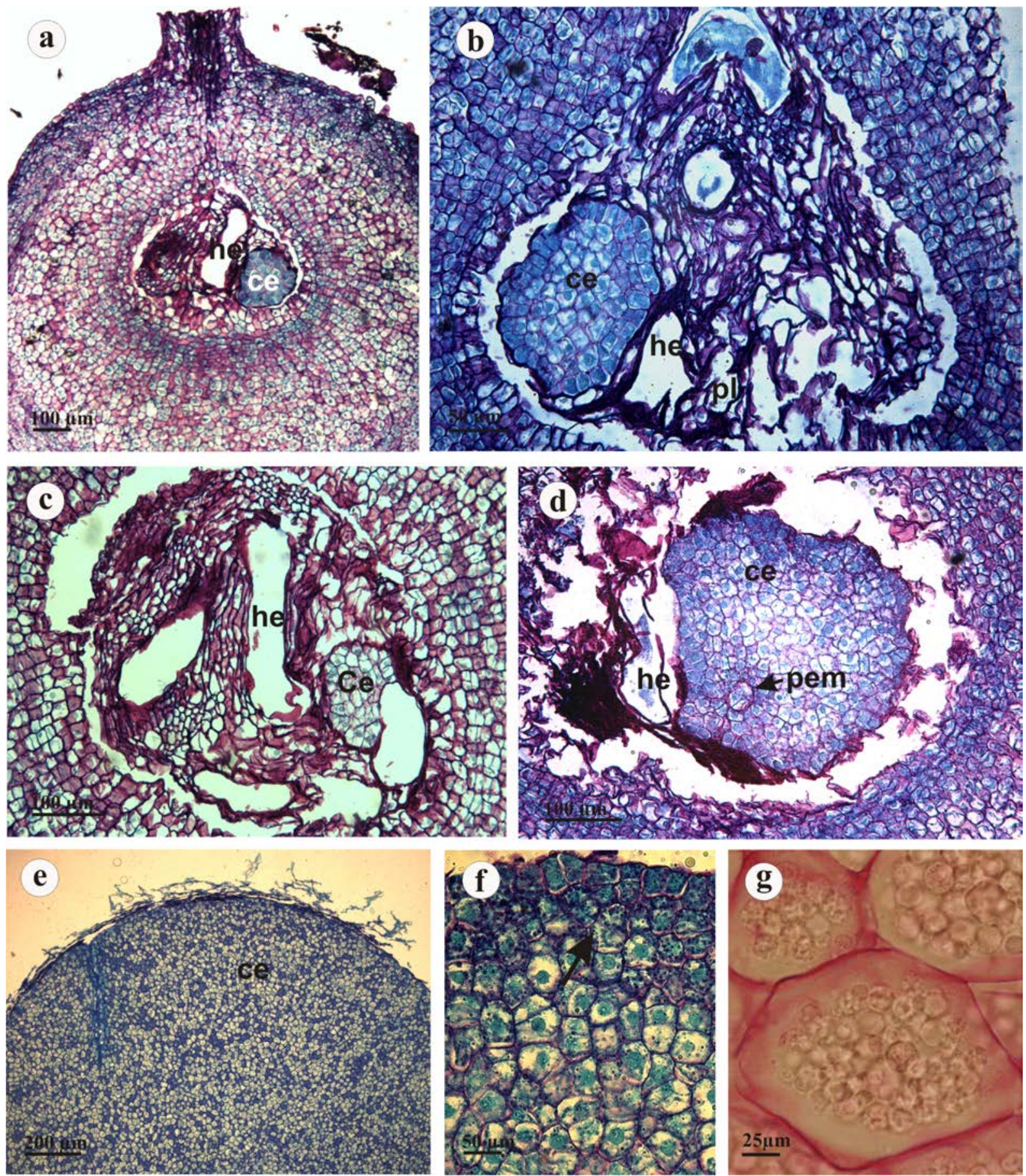

Fig. 4. Different stages of endosperm development: a, early stage showing the haustorial and cellular portions of endosperm in one ovule; $\mathbf{b}$, branching of the haustorial portion and placenta almost completely consumed; $\mathbf{c}$, a more advanced stage in which the haustorial endosperm consumes also the endocarp, the cellular portion has undergone relatively few mitotic divisions; d, later the increase in cellular endosperm occurs and the globular stage of pro-embryo is detected; e, section of seed showing endosperm totally cellular and rests of endocarp; $\mathbf{f}$, detail of starch grains in the outer layers of the endosperm (arrow); g, deposits of lipids in endosperm cells. [Abbreviations: he, haustorial endosperm; ce, cellular endosperm; pl, placenta; pem, pro-embryo.]

in Jodina the "outer exocarp" dehisces leaving exposed a white fleshy inner "exocarp", whereas in other genera, such as Cervantesia and Staufferia, the 5 perianth valves remain on the mature fruit. As mentioned above, the white inner "exocarp" corresponds to the modified nectary disk. Detailed studies about fruit wall development are not recorded in the other related genera -Cervantesia and Staufferia -. In the case of Acanthosyris, Nee (1996) stated that the fleshy layer corresponded to the mesocarp, but without conducting developmental studies. Given what was found in the present work a re-analysis of fruit development in the other genera of Cervantesiaceae will provide additional information for their systematic relationships. 

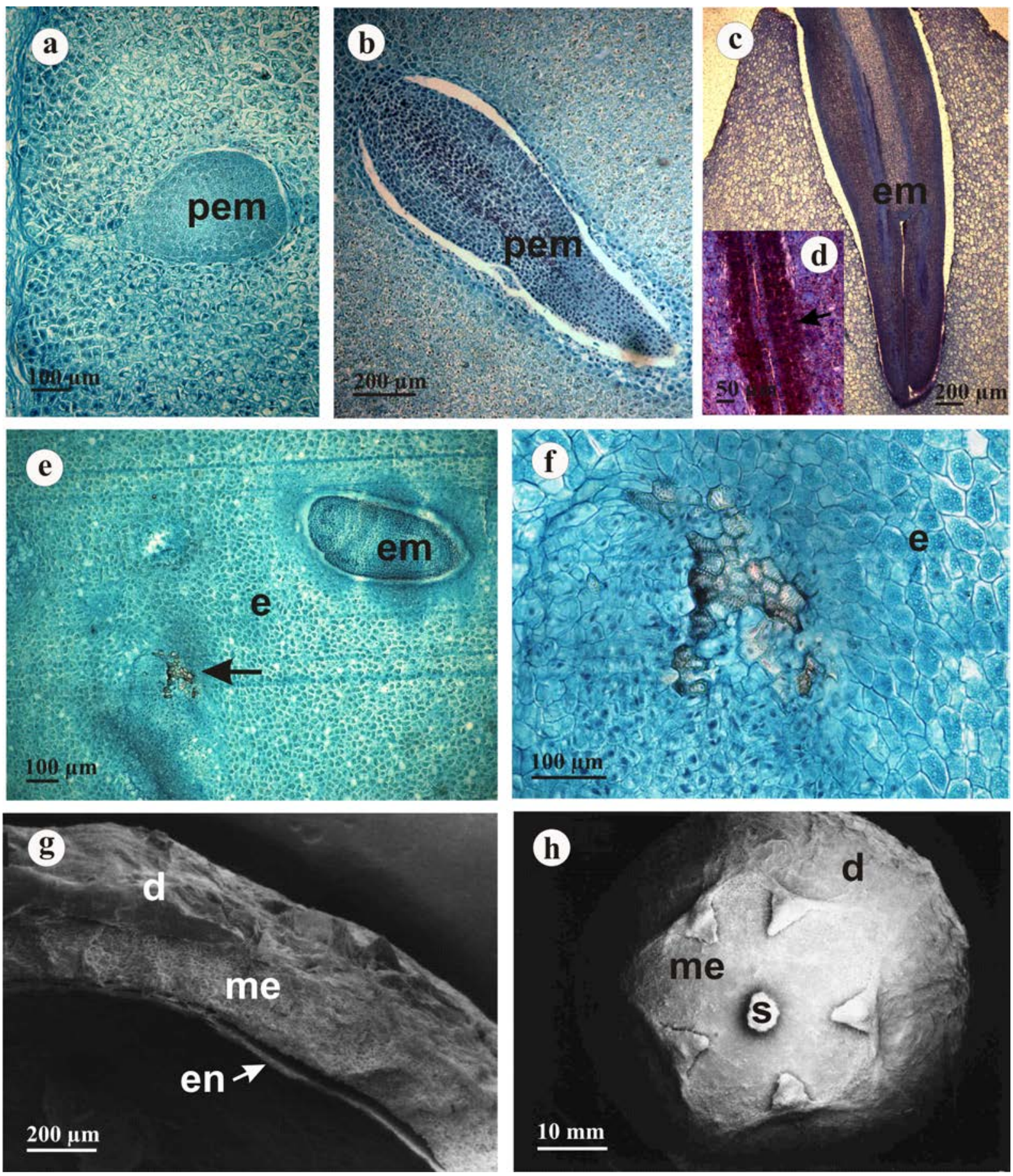

Fig. 5. Different stages of embryo development: a, early heart-shaped pro-embryo; $\mathbf{b}$, torpedo-shaped pro-embryo; $\mathbf{c}$, embryo with accumulation of starch grains in the cotyledons; $\mathbf{d}$, detail of starch grains in palisade parenchyma (arrow); e, tracheary cells (arrow) detected in the endosperm, near the embryo; f, magnification of the tracheids occurring in the endosperm; $\mathbf{g}$, detail of "seed coat"; $\mathbf{h}$, of a mature pyrene. [Abbreviations: d, rests of nectary disk; me, stony mesocarp; en, papyraceous endocarp; s, stigma.]

With respect to the development of the seed, and specifically for endospermogenesis, we registered different developmental stages of the cellular and haustorial portions of the endosperm, as described previously (Bhatnagar \& Sabharwal, 1966, 1969). Since the ovule integument was consumed by the haustorial portion of the endosperm, the resulting seed became naked and the resulting structure should be called pyrene - i.e., mesocarp plus the enclosed seed-. As for reserves contained in the endosperm, we detected protein bodies and starch grains, besides lipids previously described (Bhatnagar \& Sabharwal, 1969). Protein content of the seeds is similar to that found in Santalum acuminatum (R. Br.) A. DC. - Santalaceae s. str., Lott \& Buttrose (1978)-. Chemical studies within Cervantesiaceae would contribute to clarify more aspects of endosperm development and the seed reserves present in the genera of this family. 
As a corollary, information about the fruit type - fleshy or dry- may help to understand evolutionary and ecological aspects in angiosperms. Since the kind of fruit has been associated with different habitats (Lorts \& al., 2008), the misinterpretations of fruit types may lead to erroneous ecological or evolutionary associations. As the fruits of the Santalaceae s.l. have been interpreted as dry or fleshy by the different authors, studies like the one here presented will be fundamental to clarify such assumptions.

\section{ACKNOWLEDGEMENTS}

We thank to Dra Marisa Otegui (Department of Botany, University of Wisconsin, USA) and Dr Alcides Saénz (Universidad Nacional de La Plata) for their valuable guidance during the realization of this research. We are also grateful to the editor and the anonymous reviewers, for their valuable suggestions that improved the quality of this manuscript. This research was supported by Universidad Nacional de La Plata y Comisión de Investigaciones Científicas de la Provincia de Buenos Aires.

\section{REFERENCES}

Bhatnagar, S.O. \& Sabharwal, G. 1966. Female gametophyte and endosperm of Jodina rhombifolia Hook. et Arn. Phytomorphology 16: 588-591.

Bhatnagar, S.P. \& Sabharwal, G. 1969. Morphology and embryology of Jodina rhombifolia. Beitrage zur Biologie der Pflanzen 45: 465-479.

Bullock, D. \& Moore, K. 1992. Protein and fat determination in corn. In: Linskens, H.F. \& Jackson, J.F. (eds.), Seed analysis, pp. 181-197. Springer-Verlag Berlin Heidelberg. Berlin. https://doi.org/10.1007/ 978-3-662-01639-8_9.

Cronquist, A. 1981. An integrated system of clasification of flowering plants, pp. 268-270. Columbia University Press. New York.

Dawson, G. 1944. Las santaláceas argentinas. Revista del Museo de La Plata, secc. Botánica 6: 5-80.

Der, J.P. \& Nickrent, D.L. 2008. A molecular phylogeny of Santalaceae (Santalales). Systematic Botany 33: 107-116. https://doi.org/10.1600/ 036364408783887438.

Dettke, G.A. \& Caires, C.S. [2016]. Santalaceae. In: Lista de Espécies da Flora do Brasil. Jardim Botânico do Rio de Janeiro. [http://floradobrasil.jbrj.gov.br/jabot/floradobrasil/FB14411.]

Fulcher, R. 1982. Fluorescence microscopy of cereals. Food Microstucture 1: $167-175$.

Heide-Jørgensen, H.S. 2008. Parasitic flowering plants, pp. 104-105. Brill, Leiden. https://doi.org/10.1163/ej.9789004167506.i-438.
Johansen, D.A. 1940. Plant microtechnique. Mcgraw-Hill, New York.

Johri, B.M. \& Agarwal, S. 1965. Morphological and embryological studies in the family Santalaceae. viii. Quinchamalium chilense Lam. Phytomorphology 15: 360-372.

Kooiman, P. 1960. On the occurrence of amyloids in plants. Acta Botanica Neerlandica 9: 208-219. https://doi.org/10.1111/j.1438-8677.1960. tb00651.x.

Kuijt, J. \& Hansen, B. 2015. Santalaceae. In: Kubitzky, K. (ed.), The families and genera of vascular plants. Flowering Plants, Eudicots, Santalales, Balanophorales 12: 143-164. Springer International Publishing, Cham.

Lorts, C.M., Briggeman, T. \& Sang, T. 2008. Evolution of fruit types and seed dispersal: a phylogenetic and ecological snapshot. Journal of Systematics and Evolution 46: 396-404.

Lott, J.N.A. \& Buttrose, M.S. 1978. Thin sectioning, freeze fracturing, energy dispersive $\mathrm{x}$-ray analysis, and chemical analysis in the study of inclusions in seed protein bodies: almond, brazil nut, and quandong. Canadian Journal of Botany 56: 2050-2061. https://doi.org/10.1139/ b78-245.

Luna, M.L. \& De la Sota, E.R. 2003. Estructura foliar de Jodina rhombifolia (Santalaceae) y sus variaciones en relación al área de distribución. Iheringia, série botanica: 58: 3-12.

Luna, M.L. \& Giudice, G.E. 2005. Anatomy of the haustorium of Jodina rhombifolia (Santalaceae). Nordic Journal of Botany 24: 567-573. https://doi.org/10.1111/j.1756-1051.2004.tb01641.x.

Nee, M. 1996. A new species of Acanthosyris (Santalaceae) from Bolivia and a key to the woody south american Santalaceae. Brittonia 48: 574-579. https://doi.org/10.2307/2807878.

Nickrent, D.L., Malécot, V., Vidal-Russell, R. \& Der, J.P. 2010. A revised classification of Santalales. Taxon 59: 538-558.

O'Brien, T.P. \& Mc Cully, M.E. 1981. The study of plant structure, principles and selected methods. Thermacarphi, Melbourne.

Rodríguez Mattos, J. 1967. Santaláceas. In: Reitz, R. (ed.), Flora ilustrada catarinense 1: 1-18. Itajai.

Rogers, Z.S., Nickrent, D.L \& Malecot, V. 2008. Staufferia and Pilgerina: two new endemic monotypic arborescent genera of Santalaceae from Madagascar. Annals of the Missouri Botanical Garden 95: 391-404. https://doi.org/10.3417/2006148.

Roth, I. 1977. Fruits of angiosperms. In: Braun, H.J. \& al. (eds.), Encyclopedia of plant anatomy. Borntraeger, Berlin-Stuttgart.

Roth, I. 1987. Stratification of a tropical forest as seen in dispersal types. tasks for vegetative science 17: 189. Springer, Dordrecht, Netherlands.

Sancho, G. \& Otegui, M. 2000. Vascularization and secretory tissues in florets of Gochnatia polimorpha (Asteraceae, Mutisieae): evolutionary considerations. Phytomorphology 50: 172-179.

Spujt, R.W. 1994. A systematic treatment of fruit types. Memoirs of the New York Botanical Garden 70: 1-182.

Takhtajan, A. 1997. Diversity and clasification of flowering plants. Columbia Univ. Press. 